\title{
Persepsi Mahasiswa Terhadap Aplikasi Daring pada Pembelajaran Matematika
}

\author{
Siti Napfiah ${ }^{1)}$ \\ ${ }^{1)}$ IKIP Budi Utomo Malang, Indonesia \\ Email: napfiahsiti@gmail.com
}

\begin{abstract}
The condition of the Covid-19 pandemic have an impact on the world of education. Learning is required to use the online system (in the network). This online learning includes a new learning system so teachers need to know students' perceptions regarding online learning that applied. Especially in learning mathematics which requires an explanation of how to solve a problem. Mathematics needs special treatment when compared to non mathematical material. This study aims to describe students' perceptions of online learning. The research method used is qualitative method. The data obtained is qualitative data based on a response questionnaire filled out by students. There are two types of data, namely the form of data that can be converted into a percentage and a narrative form which is describbed in a narrative manner. Based on the research results, information is obtained that the most dominant response related to online application is through the Whatsapp application because this application has the advantage of being easy to catch a signal making it affordable for various student conditions. In addition,online learning applications can maintain the quality of learning is a combination of various applications according to the conditions of the material being studied.
\end{abstract}

Keywords : Perception, Online Application, Mathematics Learning.

\begin{abstract}
ABSTRAK
Kondisi pandemi Covid-19 ini berdampak pada dunia pendidikan. Pembelajaran diharuskan menggunakan sistem daring (dalam jaringan). Daring ini termasuk sistem pembelajaran baru sehingga pengajar perlu mengetahui persepsi yang diajar terkait pembelajaran daring yang diterapkan. Terlebih pada pembelajaran matematika yang membutuhkan penjelasan mengenai cara-cara penyelesaian suatu masalah. Matematika perlu perlakuan yang khusus jika dibandingkan dengan materi non matematika. Penelitian ini bertujuan untuk mendeskripsikan persepsi mahasiswa terhadap aplikasi daring pada pembelajaran matematika. Metode penelitian yang digunakan yaitu metode kualitatif. Data yang diperoleh merupakan data kualitatif berdasarkan angket respons yang diisi oleh mahasiswa. Bentuk datanya ada dua
\end{abstract}


macam yaitu bentuk data yang bisa diubah ke bentuk persentase dan bentuk narasi yang akan dideskipsikan secara naratif. Berdasarkan hasil penelitian diperoleh informasi bahwa respons pilihan terkait pilihan aplikasi daring yang paling dominan adalah melalui aplikasi Whatshapp karena aplikasi ini memiliki kelebihan terkait mudahnya menangkap sinyal sehingga terjangkau untuk berbagai kondisi mahasiswa. Selain itu persepsi mahasiswa terhadap aplikasi pembelajaan daring yang dapat menjaga kualitas pembelajaran adalah gabungan atau kombinasi dari berbagai aplikasi sesuai kondisi materi yang dipelajari.

Kata Kunci : Persepsi, Aplikasi Daring, Pembelajaran Matematika.

\section{PENDAHULUAN}

Kondisi pandemi Covid 19 berdampak pada sistem pendidikan di Indonesia (Rosali, 2020). Hal ini membuat kondisi pembelajaran di Indonesia harus beradaptasi dengan kondisi yang saat ini terjadi. Pandemi ini mengganggu pembelajaran yang biasanya dilakukan dengan tatap muka (Sadikin, 2020). Melihat kondisi yang seperti ini maka sudah sepantasnya pemerintah memberikan kebijakan kepada seluruh masyarakat agar pembelajarn dilakukan dengan sistem daring atau dalam jaringan. Seperti yang diungkapkan Handarini (2020) bahwa pembelajaran daring dilakukan dalam rangka memutus tali penyebaran virus corona.

Menghadapi kondisi yang mengharuskan pembelajarn dilakukan secara daring ini, IKIP Budi Utomo telah menyediakan aplikasi untuk memfasilitasi dosen dan mahasiswa dalam melaksanakan kegiatan akademik. Fasilitas yang diberikan yakni melalui aplikasi edlink. Di dalam aplikasi edlink terdapat fitur yang cukup lengkap untuk melaksanakan kegiatan pembelajaran. Mulai dari fitur untuk menyampaikan materi, mengirimkan tugas, melakukan conference, melaksanakan kuis, dan lain-lain. Sehingga dosen dan mahasiswa dapat saling berdiskusi, baik melalui conference maupun diskusi chat.

Waryanto (2006) mengatakan bahwa keunggulan pembelajaran daring adalah penyampaian pembelajaran yang tidak terbatas waktu dan ruang. Keunggulan yang lain adalah dapat meningkatkan pemerolehan informasi dari pendidikan tinggi yang berkualitas meskipun berada di lokasi yang jauh (Mustofa, 2019). Meskipun pembelajaran daring memiliki beberapa keunggulan, namun ada faktor-faktor tertentu yang perlu diperhatikan agar tercipta pembelajaran yang baik. 
Kegiatan pembelajaran daring dapat berjalan dengan baik sesuai dengan kreativitas pengajar (Dewi, 2020). Sulha (2020) juga mengatakan bahwa pengajar harus menemukan metode pembelajaran daring yang tepat di era pandemi ini. Sedangkan Nguyen (2015) mrngatakan bahwa keefektifan belajar daring juga tergantung pada lingkungan. Di sisi lain, Sofyana (2019) mengatakan bahwa pembelajaran daring kombinasi Whatshap lebih efektif daripada pembelajaran konvensional untuk diterapkan pada kelas karyawan. Sedangkan Mustakim (2020) mengungkapkan bahwa kualitas pembelajaran daring pada matematika dapat ditingkatkan dengan memperhatikan beberapa hal diantaranya yaitu memberikan materi yang ringkas, jika materi dalam bentuk video harus memperhatikan bahasa yang baik serta kapasitas video jangan terlalu berat, harus memberikan materi sebelum memberikan tugas, dan soal yang diberikan bervariasi.

\section{METODE PENELITIAN}

Penelitian ini merupakan penelitian kualitatif. Tujuan dari penelitian ini adalah mendeskripsikan persepsi mahasiswa tehadap pembelajaran daring. Penelitian ini dilaksanakan pada tahun 2020 di IKIP Budi Utomo Malang. Subjek penelitiannya adalah mahasiswa Program Studi Pendidikan Matematika IKIP Budi Utomo Malang. Instrumen yang digunakan dalam pengambilan data yaitu angket yang dibuat melalui Google Form. Teknik pengumpulan data yang dilakukan yaitu mahasiswa diminta mengisi angket pada Google Form yang telah dibuat mengenai pendapat mereka terkait pembelajaran daring. Isi angket tersebut adalah mahasiswa diminta memilih aplikasi pembelajaran daring apa yang disukai dan mahasiswa diminta untuk menyampaikan pendapatnya mengenai pemeblajarran daring. Setelah semua mahasiswa mengisi angket tersebut maka data terkumpul dan selanjutnya dilakukan tahap analisis data. Data yang dianalisis ada dua macam yaitu data pertama tentang persentase pemilihan aplikasi daring yang dipilih mahasiswa dan data kedua mengenai pendapat mahasiswa mengenai pembelajaan daring. 


\section{HASIL DAN PEMBAHASAN}

Isi dari angket pada Google Form yang telah disebarkan ke mahasiswa ada dua pertanyaan. Pertama, pertanyaannya adalah pilih aplikasi daring apa yang disukai. Kedua, berikan alasan dari pemilihan pembelajaran daring tersebut.

Pertanyaan pertama ini merupakan bentuk multiple choice atau banyak pilihan. Pilihan yang disediakan diantaranya yaitu aplikasi edlink, Zoom, Google Meet, Whatshap, dan lain-lain. Pada pilihan "dan lain-lain”, mahasiswa diminta mengisi aplikasi apa yang dimaksud. Jadi mahasiswa bisa mengisi aplikasi yang disukai diluar pilihan yang disediakan. Berdasarkan data yang terkumpul dari 45 mahasiswa diperoleh hasil seperti pada tabel berikut.

Tabel 1.Tabel Pemilihan Aplikasi Daring yang Disukai

\begin{tabular}{ccc}
\hline Aplikasi Daring & $\begin{array}{c}\text { Jumlah Mahasiswa } \\
\text { yang Memilih }\end{array}$ & $\begin{array}{c}\text { Persentase Banyaknya } \\
\text { Mahasiswa yang Memilih }\end{array}$ \\
\hline Edlink & 8 & $18 \%$ \\
Zoom & 8 & $18 \%$ \\
Google Meet & 6 & $13 \%$ \\
Whatsapp & 12 & $27 \%$ \\
Gabungan & 9 & $20 \%$ \\
\hline
\end{tabular}

Sesuai tabel tersebut, dapat dibuat diagram seperti gambar berikut.

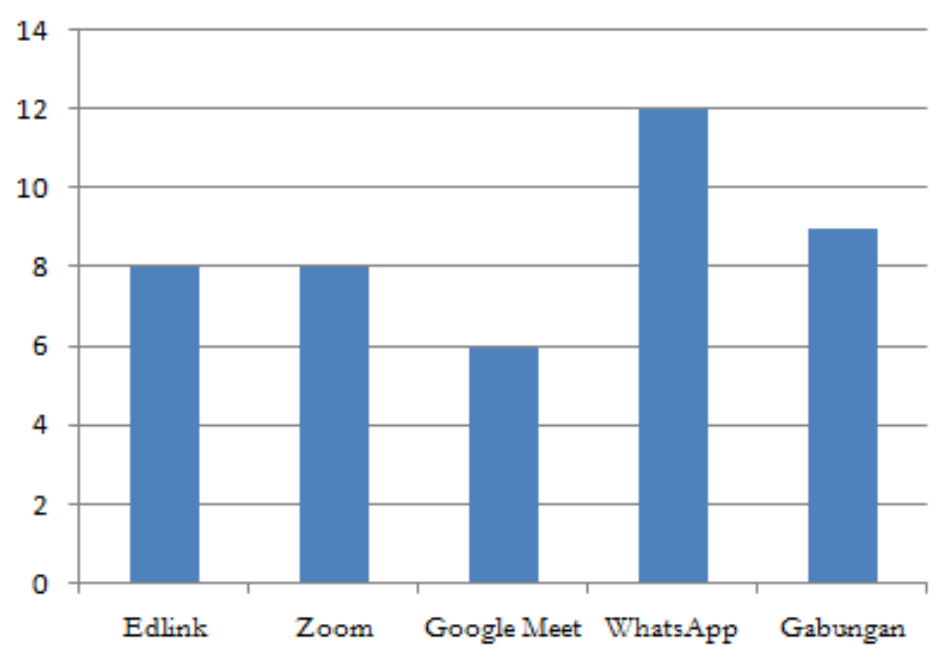

Gambar 1. Banyaknya Mahasiswa yang Memilih Aplikasi Pembelajaran Daring

Berdasarkan tabel dapat diketahui persentase banyaknya mahasiswa yang memilih aplikasi daring sebagai pembelajaran yang disukai dengan rincian sebagai 
berikut. Sebanyak $18 \%$ mahasiswa memilih pembelajaran daring melalui aplikasi delink, 18\% mahasiswa memilih pembelajaran daring melalui aplikasi Zoom, 13\% mahasiswa memilih pembelajaran daring melalui aplikasi Google Meet, 27\% mahasiswa memilih pembelajaran daring melalui aplikasi Whatsapp, 20\% mahasiswa memilih pembelajaran daring melalui gabungan dari beberapa aplikasi. Berdasarkan data ini maka diketahui bahwa peminat terbanyak untuk pembelajaran daring adalah melalui aplikasi Whatsapp dengan persentase sebesar $27 \%$.

Pertanyaan kedua dari angket adalah pendapat mahasiswa mengenai pembelajaran daring. Berikut beberapa pendapat yang diberikan oleh mahasiswa terkait pembelajaran daring yang selama ini diterapkan oleh dosen.

Pendapat mahasiswa memilih belajar melalui aplikasi edlink adalah di dalam edlink bisa melakukan conference dan mengirim pesan untuk diskusi, bisa mengirim tugas langsung melalui edlink dan tertera jelas deadlinenya, bisa presensi langsung ke bagian kampus pusat, dan menghemat penyimpanan data telepon seluler. Namun ada beberapa mahasiswa menyampaikan kelemahan belajar melalui edlink adalah karena membutuhkan sinyal yang kuat sehingga bagi mahasiswa yang rumahnya jauh dari sinyal yang kuat maka akan terkendala untuk ikut belajar melalui edlink karena membutuhkan waktu yang lama dalam setiap proses yang dilakukan.

Terdapat mahasiswa yang lebih suka memakai aplikasi Zoom karena lebih paham jika dijelaskan dengan melihat dan mendengar penjelasan dari dosen sehingga bisa berdiskusi langsung dengan dosen seperti belajar tatap muka. Tetapi beberapa mahasiswa kurang suka belajar melalui aplikasi Zoom karena membutuhkan sinyal yang kuat sehingga ketika jaringan tidak kuat maka akan leave dengan sendirinya, atau terkadang sinyalnya putus-putus sehingga suara yang terdengar putus-putus ketika mendengarkan penjelasan dari dosen atau sebaliknya ketika mahasiswa memberikan menjawab, suaanya tidak terdengar oleh dosen kaena faktor sinyal. Mahasiswa lain berpendapat bahwa memakai Zoom sering tidak ada jaringan sehingga kurang efisien jika digunakan pada mata kuliah matematika yang berhubungan dengan menghitung, materi seperti kurang terserap jika hanya dilampirkan pada share screen Zoom sehingga mudah lupa.

Aplikasi yang selanjutnya adalah Google Meet. Ada mahasiswa yang lebih suka menggunakan aplikasi Google Meet dibandingkan dengn Zoom karena sinyal di 
Google Meet lebih stabil dan lebih jernih. Beberapa mahasiswa mengungkapkan bahwa kurang suka memakai Google Meet karena ketika sinyal kurang kuat maka suara dosen kurang terdengar dan jika melalui conference seperti Google Meet ini, materi kurang mudah diserap.

Aplikasi berikutnya yaitu Whatsapp. Mahasiswa yang suka menggunakan aplikasi Whatshap mengatakan bahwa sinyal yang dibutuhkan tidak terlalu tinggi sehingga bisa mengikuti diskusi dengan lancar tanpa terkendala sinyal, materi bisa lebih mudah dipahami jika melihat video pembelajaran yang dikirim pada Whatshap karena video bisa dipelajari berulang-ulang dan didiskusikan bersama lewat grup Whatsapp, karena jika kita belum mengerti atau ketinggalan karena susah sinyal masih bisa scroll ulang. Tetapi ada mahasiswa yang mengatakan jika belajar melalui Whatshap mudah bosan.

Pilihan selanjutnya adalah untuk pilihan "dan lain-lain". Untuk pilihan ini, ternyata mahasiswa mengisi dengan jawaban gabungan atau kombinasi dari beberapa aplikasi. Mahasiswa yang memilih pembelajaran daring secara gabungan memberikan alasan berikut.

Aplikasi Zoom kombinasi Whatsapp. Zoom bisa digunakan untuk diskusi secara langsung, namun tidak harus setiap pertemuan, misal satu bulan satu kali setiap mata kuliah. Dikombinasi dengan share video interaktif di WA group karena video bisa di play berulang-ulang sampai paham dan jika tidak paham bisa diskusi sambil bertanya di grup Whatsapp. Diskusi chat lebih suka di grup Whatsapp daripada komen di delink karena di edlink butuh sinyal kuat sehingga loadingnya lama.

Ada mahasiswa yang memilih semua aplikasi yang ditawarkan karena dengan kombinasi maka bisa lebih memahami materinya, dimana Zoom ataupun Google Meet mahasiswa bisa melihat dosen saat menjelaskan, Whatshap untuk diskusi dan edlink untuk mengumpulkan tugas yang sudah ada deadline jadi tidak membuat lupa adanya tugas. Selain itu ada mahasiswa yang memberikan pendapat bahwa kalau memilih salah satu aplikasi pasti ada kendalanya, jadi fleksible sesuai dengan kebutuhan saat itu saja.Setiap pembelajaran dalam masa pandemi ini ada kurang dan lebihnya. Kita harus pintar-pintar memahami materi yang diberikan dosen, kalau misalkan kuliah lewat grup wa saja tidak memahami sama sekali materi 
yang diberikan, kalau misalkan pembelajaran lewat Zoom maka sedikit bisa memahami materi tapi terkadang terkendala sinyal dan kuota. Kalau misalkan dosen memberikan video pembelajaran maka sangat membantu sekali. Jadi pembelajarannya dikombinasi saja.

Selain pendapat yang telah dikemukakan tersebut, ada beberapa mahasiswa memberikan pendapat sebagai berikut. Mahasiswa berpendapat bahwa belajar yang berbasis conference pada edlink, Zoom, atau Google Meet bisa lebih mudah dipahami karena dosen bisa menjelaskan sambil menulis di papan. Ada juga mahasiswa yang memberikan pendapat yaitu tergantung jenis mata kuliahnya, jika mata kuliah materi matematika murni maka lebih enak dengan melihat video interaktif melalui grup Whatsapp, tapi kedua pihak harus aktif, baik pengajar maupun yang diajar. Namun jika untuk mata kuliah non matematika lebih suka memakai conference.

Berdasarkan hasil penelitian tersebut, diperoleh informasi bahwa setiap aplikasi memiliki kelebihan dan kekurangan. Aplikasi edlink memiliki kelebihan yaitu fitur yang lengkap, namun kelemahnanya dalah aplikasi ini membutuhkan sinyal yang kuat untuk setiap prpses yang dilakukan di dalamnya. Untuk aplikasi yang berbasis conference seperti Zoom dan Google Meet memiliki kelebihan yaitu mahasiswa dapat bertatap muka dengan dosen sehingga selayaknya kuliah di kelas. Namun aplikasi berbasis conference memiliki kelemahan yakni terkait sinyal yang kurang stabil sehingga mengakibatkan kurang lancar dalam mengikuti kegiatan pembelajaran. Sedangkan aplikasi Whatshapp memiliki kelebihan yaitu mudahnya mencari sinyal sehingga ketika dosen mengirim video interaktif di Whatshapp maka mudah untuk didownload dan video ini dapat diputar berulang-ulang untuk memahami materi, begitu pula untuk diskusi yang dilakukan pada Whatshapp dapat dibaca ulang kapanpun sesuai kebutuhan. Hal ini sesuai dengan pendapat Waryanto (2006) bahwa keunggulan pembelajaran daring adalah penyampaian pembelajaran yang tidak terbatas waktu.

Melihat kondisi bahwa setiap aplikasi memiliki kelebihan dan kelemahan masing-masing maka pengajar harus pandai mengkombinasikan aplikasi daring yang efektif agar materi pembelajaran dapat tersampaikan kepada peserta didik dengan baik. Hal ini sesuai dengan pendapat Dewi (2020) yang mengatakan bahwa kegiatan pembelajaran daring dapat berjalan dengan baik sesuai dengn kreativitas pengajar. 
Sulha (2020) juga mengatakan bahwa pengajar harus menemukan metode pembelajaran daring yang tepat di era pandemi ini.

Khusus untuk perkuliahan matematika, kombinasi aplikasi daring yang sesuai yaitu sebagai berikut. Pertama, pengajar mengirim video interaktif yang bagus dengan kapasitas kecil melalui aplikasi Whatsapp agar mudah didownload peserta didik. Hal ini sesuai dengan yang diungkapkan Mustakim (2020) bahwa kualitas pembelajaran daring pada matematika dapat ditingkatkan dengan memberikan materi dalam bentuk video yang mana video tersebut harus menggunakan bahasa yang baik serta kapasitas video jangan terlalu berat. Kedua, melakukan diskusi pada aplikasi Whatsapp. Hal ini sejalan dengan pernyataan Kristina (2020) bahwa aplikasi yang paling banyak digunakan dalam pebelajaran daring adalah aplikasi Whatsapp. Ketiga, jika diskusi pada Whatsapp kurang memfasilitasi dengan baik, maka dilakukan conference melalui Zoom atau Google Meet maupun fitur conference pada edlink. Keempat, penugasan dilakukan melalui delink karena pada edlink terdapat deadline pengumpulan sehingga tidak membuat lupa adanya tugas.

\section{SIMPULAN}

Berdasarkan penelitian yang telah dilakukan, dapat disimpulkan bahwa respons pilihan aplikasi pembelajaran daring yang paling dominan adalah melalui aplikasi Whatshapp karena aplikasi ini memiliki kelebihan terkait mudahnya menangkap sinyal sehingga terjangkau untuk berbagai kondisi mahasiswa. Selain itu, mahasiswa memberikan persepsi dalam pemilihan aplikasi pembelajaran daring yang dapat menjaga kualitas pembelajaran matematika adalah gabungan atau kombinasi dari berbagai aplikasi sesuai kondisi materi yang dipelajari.

\section{REFERENSI}

Dewi, Wahyu Aji Fatma. 2020. Dampak Covid terhadap Implementasi Pembelajaran Daring di Sekolah Dasar. Jurnal Edukatif, 2(1), 55-61.

Handarini, Oktafia Ika. 2020. Pembelajaran Daring sebagai Upaya Study from Home (SFH) Selama Pandemi Covid 19. Jurnal Pendidikan Administrasi Perkantoran, 8(3), 496-503. 
Hanum, N.S. 2013. Keefektifan E-Learning sebagai Media Pembelajaran (Studi Evaluasi Model Pembelajaran E-Learning SMK Telkom Sandhy Putra Purwokerto). Jurnal Pendidikan Vokasi, 3(1), 90-102.

Harahap, S.A., dkk. 2021. Problematika Pembelajaran Daring dan Luring Anak Usia Dini bagi Guru dan Orang Tua di Masa Pandemi Covid 19. Jurnal Obsesi, $5(2)$.

Jannah, R. dan Harri S. 2021. Tingkat Stress Mahasiswa Mengikuti Pembelajaran Daring pada Masa Pandemi Covid-19. Jurnal Riset dan Pengabdian Masyarakat, 1(1), 130-146.

Kristina, M., dkk. 2020. Model Pelaksanaan Pembelajaran Daring pada Masa Pandemi Covid-19 di Provinsi Lampung. Jurnal Idaarah, 4(2), 200-209.

Mustakim. 2020. Efektivitas Pembelajaran Daring Menggunakan Media Online Selama Pandemi Covid 19 pada Mata Pelajaran Matematika. Jurnal Al Asma, 2(1), 1-12.

Mustofa, M.I., M. Chodzirin, dan Lina S. 2019. Formulasi Model Perkuliahan Daring sebagai Upaya Menekan Disparitas Kualitas Perguruan Tinggi. Walisongo Journal of Information Technology, 2(2), 151-160.

Nguyen, Tuan. 2015. The Effectiveness of Online Learning: Beyond No Significant Difference and Future Horizons. MERLOT Journal of Online Learning and Teaching, 11(2), 309-319.

Rosali, Ely Satiyasih. 2020. Atifitas Pembelajaran Daring pada Masa Pandemi Covid-19 di Jurusan Pendidikan Geografi Universitas Siliwangi Tasikmalaya. Jurnal Geosee, 1(1), 21-30.

Sadikin, Ali dan Afreni Hamidah. 2020. Pembelajaran Daring di Tengah Wabah Covid 19. Jurnal BIODIK, 6(2), 214-224.

Sofyana, Latjuba dan Abdul Rozaq. 2019. Pembelajaran Daring Kombinasi Berbasis Whatshapp pada Kelas Karyawan Prodi Teknik Informatika Universitas PGRI Madiun. Jurnal JANAPATI, 891), 81-86.

Sulha. 2020. Penerapan Montessori dalam Pembelajaran Matematika melalui Luring sebagai Alternatif Masa Pandemi.Jurnal Prismatika, 3(1), 22-30.

Sutini, dkk. 2020. Efektivitas Pembelajaran Daring dengan Menggunakan ELearning Madrasah terhadap Optimalisasi Pemahaman Matematika Siswa. JRPM: Jurnal Review Pembelajaran Matematika, 5(2), 124-136.

Waryanto, Nur Hadi. 2006. On-line Learning sebagai Salah Satu Inovasi Pembelajaran. Jurnal Pythagoras, 2(1), 10-23. 